\title{
Squamous cell carcinoma of the oral cavity and the oropharynx in patients less than 40 years of age: a 20-year analysis
}

Samuel E Udeabor ${ }^{1}$, Majeed Rana², Gerd Wegener ${ }^{3}$, Nils-Claudius Gellrich² and André M Eckardt ${ }^{2 *}$

\begin{abstract}
Background: Squamous cell carcinoma mainly afflicts patients older than 40 years of age however, few cases are seen in younger patients. The aim of this study therefore was to determine the incidence of squamous cell carcinoma of the oral cavity and oropharynx in patients less than 40 years of age with a view to assessing the prognosis over a period of time.

Methods: This was a 20 years retrospective review of patients who were histologically diagnosed with squamous cell carcinoma of the oral cavity and the oropharynx at the Department of Cranio-Maxillo-Facial Surgery of the Hannover Medical School, Germany and had not received treatment anywhere else. Records of these patients were analysed for age and sex distribution, tumour staging and differentiation, location, treatment given, recurrences and metastasis, time between diagnosis and death or last contact with patient, and possible cause of death.

Comparisons were also made with patients older than 40 years of age.

Results and discussion: A total of 977 patients treated for squamous cell carcinoma of the oral cavity and the oropharynx in the 20-year period of this study were included. Thirty eight (3.9\%) of the overall patient population were under 40 years of age. Among these, 30 (78.9\%) were males and $8(21.1 \%)$ were females. The incidence was highest in the 30-39 year age group accounting for 31 (81.6\%) of the 38 patients. The moderately differentiated carcinoma was commonest $(24 ; 63.2 \%)$. The floor of the mouth had the highest number of tumours $(15 ; 39.5 \%)$, but none was seen in the oropharynx. Surgery alone was the main stay of treatment given to 26 (68.4\%) patients. At the end of the study period, 13 (34.2\%) patients had died of the tumour and the 5-year survival rate was 66.2\%. In the older patient group (>40 years), $42.7 \%$ died from the tumour and the 5 -year survival rate was $57.6 \%$.
\end{abstract}

Conclusion: The results from the present study showed that young adults may have a better prognosis especially in terms of long term overall survival from oral and oropharyngeal carcinoma.

Keywords: Squamous cell carcinoma, Prognosis, Oral cavity, Oropharynx, Young adults

\section{Background}

Squamous cell carcinoma (SCC) in the head and neck region occurs primarily in the oral cavity and oropharynx and is generally regarded as a disease of the elderly [1]. Majority are seen in patients over the age of 40 years, whereas the tumour remains very uncommon among young adults [2]. A review of literature revealed

\footnotetext{
* Correspondence: eckardt.andre@mh-hannover.de

${ }^{2}$ Department of Cranio-Maxillofacial Surgery, Hannover Medical School, CarlNeuberg-Strasse 1, 30625, Hannover, Germany

Full list of author information is available at the end of the article
}

that the incidence of SCC of the oral cavity (OC) and the oropharynx (OP) in young adults ranges between 1$6 \%$ [3-5] with the tongue frequently reported as the commonest location for this tumour[4].

It is logical to assume that the fewer cases of this tumour in young patients are due to the considerable shorter exposure period to the risk factors of alcohol and tobacco when compared to the elderly patients [3]. However, some cases have been reported in non-smoking, non-alcohol drinking youths which then raises the question as to other possible aetiological factors in this young population $[6,7]$.

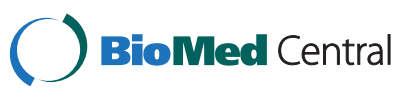


There is no agreement among various reports on the prognosis of SCC of the OC and OP in young adults. While some claim that there is no difference in prognosis between the disease in the elderly and the young adult patients $[8,9]$, others report a worse prognosis in the young adults and therefore recommend a more aggressive management regime for this group [10].

We therefore present our experience in the management of patients with SCC of the OC and the OP over a 20-year period with particular attention to patients less than 40 years of age and also making comparisons to older patients above 40 years.

\section{Methods}

The records of patients who were histologically diagnosed with squamous cell carcinoma of the oral cavity and the oropharynx at the Department of Cranio-Maxillo-Facial Surgery of the Hannover Medical School, Germany between 1980 and 1999 were retrospectively reviewed. Patients included in this study must not have been treated for their cancer anywhere else.

The data extracted were analysed for demographic information, tumour differentiation, size, location, treatment given, recurrences, second primaries and metastasis, time between diagnosis and death or last contact with patient, and possible cause of death. Patients were divided into 9 groups according to their ages at diagnosis: Group 1 (10-19 years); group 2 (2029 years); group 3 ( $30-39$ years); group 4 ( $40-49$ years); group 5 (50-59 years); group 6 (60-69 years); group 7 (70-79 years); group 8 (80-89 years); and group 9 (90 years and above). TNM system was used for the tumour staging whereas the location was categorised using the International Classification of Diseases of the WHO into:

- ICD-141 (Tongue),

- ICD-143-143.13 (Mandibular and Maxillary mucosa),

- ICD-144-144.9 (Floor of the mouth),

- ICD-145-145.9 (Other parts of the mouth),

- ICD-146-146.2 (Tonsillar region) and

- ICD-146.6-146.9 (Oropharynx).

Treatment given to the patients was divided into surgery, radiotherapy, chemotherapy, hormone therapy, a combination of these or none. Statistical analysis was done using SPSS for windows (version 9.0) and the calculation of survival rates for the groups less than 40 years and those above 40 was done using the Kaplan-Meier estimates. Log-rank test was the statistical test used and a result is considered significant when $\mathrm{p}$ is $<0.05$.

\section{Results}

\section{Demographics}

A total of 977 previously untreated patients, with histologically diagnosed SCC of the OC and the OP were seen within the period under review in this study. Male patients were 733 (75\%), and female patients 244(25\%) and the mean age for the general patients population was 57.6.

Thirty eight $(3.9 \%)$ of the overall patient population were under 40 years of age, and $30(78.9 \%)$ of them were males and $8(21.1 \%)$ female. The youngest male patient at diagnosis was 24 years old and the youngest female patient 19 years. (Table 1 )

\section{Tumour differentiation grading}

Among the patients less than 40 years of age, 24 (63.2\%) had moderately differentiated SCC, $7(18.4 \%)$ had well differentiated tumour and $5(13.2 \%)$ had poorly differentiated tumour. Information regarding histological differentiation could not be found for 2 patients in this age group. Tables 2 and 3 show the histological differentiation in the general population and in those less than 40 years respectively.

\section{Tumour location}

The floor of the mouth was the commonest site of tumour occurrence both in the general population and in patients less than 40 years of age. This accounted for $42.2 \%$ in the general patient population and $39.5 \%$ in the group less than 40 years. Only in $1.3 \%$ of the overall patient population was the tumour located in the orophaynx and none was found in the oropharynx of the young patient group. (Tables 4 and 5)

Table 1 Age and gender distribution of the general patients population $(n=977)$

\begin{tabular}{lcccl}
\hline $\begin{array}{l}\text { Age in years at } \\
\text { diagnosis of SCC }\end{array}$ & $\begin{array}{l}\text { Number of } \\
\text { Patients }\end{array}$ & male & female & $\begin{array}{l}\text { percentage } \\
\text { (\%) }\end{array}$ \\
\hline $15-19$ & 1 & 0 & 1 & 0,1 \\
\hline $20-29$ & 31 & 26 & 5 & 3,2 \\
\hline $30-39$ & 222 & 182 & 40 & 22,7 \\
\hline $40-49$ & 358 & 289 & 69 & 36,6 \\
\hline $50-59$ & 211 & 154 & 57 & 21,6 \\
\hline $60-69$ & 104 & 57 & 47 & 10,6 \\
\hline $70-79$ & 43 & 20 & 23 & 4,4 \\
\hline $80-89$ & 1 & 1 & 0 & 0,1 \\
\hline$\geq 90$ & $\mathbf{9 7 7}$ & $\mathbf{7 3 3}$ & $\mathbf{2 4 4}$ & $\mathbf{1 0 0}$ \\
\hline Total & 57,6 & 56,3 & 61,4 & \\
\hline Average age in years & & & &
\end{tabular}


Table 2 Histological grade of differentiation (all patients)

\begin{tabular}{lcl}
\hline Histological Differentiation & $\mathbf{n}$ & \\
\hline & \multicolumn{1}{l}{ (41 } \\
\hline well differentiated & 672 & $14,4 \%$ \\
\hline moderately differentiated & 105 & $68,8 \%$ \\
\hline 3 poorly differentiated & 2 & $10,7 \%$ \\
\hline 4 undifferentiated, anaplastic & 920 & $0,2 \%$ \\
\hline Value & 57 & $94,2 \%$ \\
\hline missing & 977 & $5,8 \%$ \\
\hline Total & & $100 \%$
\end{tabular}

\section{Tumour staging}

As at the time of diagnosis, $\mathrm{T}_{1}$ tumours occurred most frequently, accounting for $32.0 \%$ of the whole patient population. Males were seen to have larger tumours at presentation than females with a p-value of 0.005 which is highly significant. However, there was no significant difference between the groups of patients less than 40 years and those older than 40 years. (Figures 1 and 2)

\section{Treatment}

Information regarding treatment could not be found for $21(2.1 \%)$ patients and $4(0.4 \%)$ patients received no treatment at all. However, surgery was the only treatment given to $67.5 \%$ of the general population, while $14.8 \%$ had surgery in combination with chemotherapy or radiotherapy. Only $1.5 \%$ had radiotherapy alone, $1.3 \%$ had chemotherapy and $0.1 \%$ had hormone therapy. In the group of patients less than 40 years, surgery alone was the treatment in $26(68.4 \%)$ patients, surgery in combination with chemotherapy and/or radiotherapy was used for $9(23.7 \%)$ patients and 3 (7.9\%) patients had only chemotherapy plus radiotherapy.

\section{Second primaries, recurrences and metastasis}

Secondary tumours developed in 112 patients $(11.5 \%)$ during the study period, 190 patients (19.4\%) had recurrences, 388 patients $(39.7 \%)$ showed signs of clinical metastasis and in 54 other patients (5.5\%), there was distant metastasis.

Table 3 Histological grade of differentiation (patients younger than $\mathbf{4 0}$ years)

\begin{tabular}{lcl}
\hline Histological Differentiation & & \\
\hline 1 well differentiated & $\mathbf{n}$ & $\%$ \\
\hline 2 moderately differentiated & 7 & $18,4 \%$ \\
\hline 3 poorly differentiated & 24 & $63,2 \%$ \\
\hline Value & 5 & $13,2 \%$ \\
\hline Missing & 36 & $94,7 \%$ \\
\hline Total & 2 & $5,3 \%$ \\
\hline
\end{tabular}

Table 4 Tumour location for all patients

\begin{tabular}{lll}
\hline $\begin{array}{l}\text { Tumour Location(simplified } \\
\text { according to ICD) }\end{array}$ & $\begin{array}{l}\text { Number of } \\
\text { Patients }(\mathbf{n})\end{array}$ & percentage (\%) \\
\hline Tongue & 220 & 22,5 \\
\hline Floor of the mouth & 412 & 42,2 \\
\hline Other parts of the mouth & 152 & 15,6 \\
\hline Mandibular and Maxillary mucosa & 131 & 13,4 \\
\hline Tonsillar region & 49 & 5,0 \\
\hline Oropharynx & 13 & 1,3 \\
\hline Total & $\mathbf{9 7 7}$ & $\mathbf{1 0 0}$ \\
\hline
\end{tabular}

Local recurrence-free survival

Comparison of the local recurrence-free survival for the group less than 40 years and the group above 40 years using the log-rank test yielded no significant result $(\mathrm{p}=0.1209)$. (Figure 3$)$

\section{Cause of death and survival analysis}

By the end of the study period, 418 patients $(42.8 \%)$ had died of the tumour, while 559 patients (57.2\%) were still alive. A further breakdown revealed that the overall 5year survival rate was $57.9 \%, 10$-year survival rate was 46.9\%, and 15-year survival was $30.9 \%$. (Figure 4 )

Among the 38 patients less than 40 years of age, 13 patients (34.2\%) had died of the tumour at the end of the study period, while the 25 other patients $(65.8 \%)$ were still alive or their death was not caused by the tumour. The 5-year survival rate for this group was $66.2 \%$. (Figure 5)

Furthermore, for the group 40 years and older, 401 (42.7\%) patients had died of the tumour at the end of the study period, with a 5-year survival rate of $57.6 \%$. (Figure 5)

\section{Discussion}

Many conflicting results have been reported regarding whether age at diagnosis influences prognosis of squamous cell carcinoma of the head and neck region

Table 5 Tumour location in patients younger than 40 years of age

\begin{tabular}{lcccl}
\hline $\begin{array}{l}\text { Tumour } \\
\text { Location (simplified } \\
\text { according to ICD) }\end{array}$ & $\begin{array}{l}\text { Number of } \\
\text { Patients }(\mathbf{n})\end{array}$ & males & females & $\begin{array}{l}\text { Percentage } \\
\text { (\%) }\end{array}$ \\
\hline Tongue & 13 & 9 & 4 & 34,2 \\
\hline Floor of the mouth & 15 & 13 & 2 & 39,5 \\
\hline Other parts of the mouth & 3 & 2 & 1 & 7,9 \\
\hline Mandibular and & 4 & 3 & 1 & 10,5 \\
Maxillary mucosa & & 3 & 0 & 7,9 \\
\hline Tonsillar region & 3 & 0 & 0 & 0 \\
\hline Oropharynx & 0 & $\mathbf{3 0}$ & $\mathbf{8}$ & $\mathbf{1 0 0}$ \\
\hline Total & $\mathbf{3 8}$ & & & \\
\hline
\end{tabular}




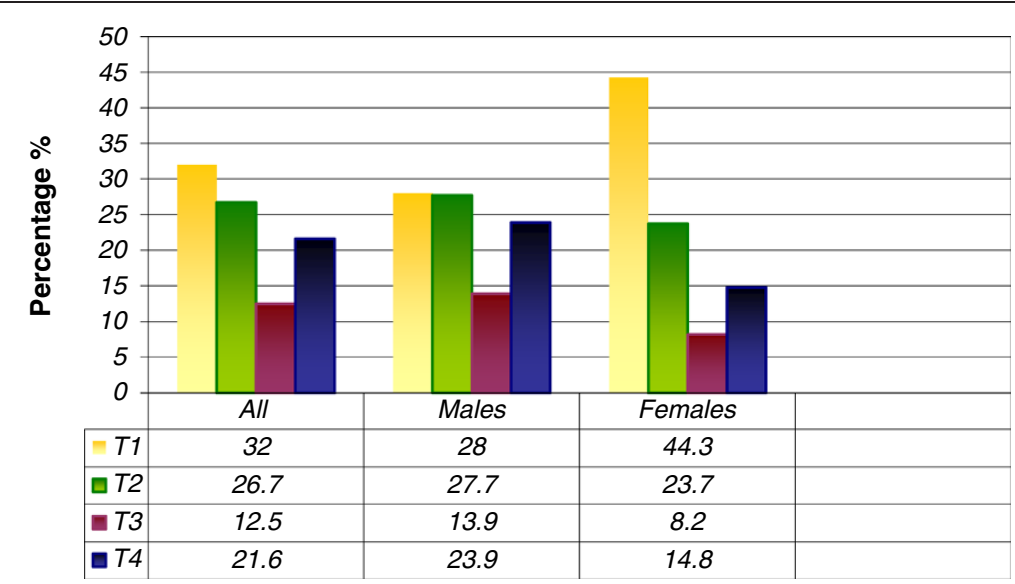

Figure 1 T-stages (based on T1-T4) and sex of the patients $(\mathbf{n}=\mathbf{9 7 7})$. A comparison of men versus women using the log-rank test showed a highly significant result $(p=0.005)$.

$[1,2,4,8-12]$. We present in this report our own experience in the management of these young patients over a 20-year period with comparison also to the older patients' population seen within the same study period. An incidence of $3.9 \%$ of SCC of the OC and OP in patients less than 40 years of age found in this study compares favourably with other similar reports, thus confirming the rarity of this tumour in young patients $[13,14]$. Hart et al. [1] however reported an incidence of $15.75 \%$ which is significantly higher than the results found in other literature. The authors noted that their small sample size and the overwhelming young population in attendance to their hospital may have contributed to the high incidence rate.

There is a general agreement in the literature of a higher male preponderance of SCC of the OC and OP in young patients [4,15-18]. A male to female ratio of 3.8:1 observed among the young patient group in our study is a bit higher than a few other reports which gave the gender ratio to be 1.6:1 [15], 1.7:1 [4], 1.9:1 [16], and 2.3:1 [17]. Our result on the other hand is far less than 6.7:1 male to female ratio reported by Cusumano and Persky [18]. Geographic locations and social lifestyles among different world populations might have accounted for these variations.

The tongue is reported as the most common location for head and neck SCC in the young adults $[1,2,4,19]$. This differs from the findings from the present study in which the tongue is second only to floor of the mouth as the commonest location. However, considering women in this young age group alone, the tongue was by far the preferred site accounting for $50 \%$ of the tumour location. This agrees with the findings of Patel et al. [7] who reported an increasing incidence of oral tongue SCC among young white women. Significantly, no tumour was located in the oropharynx of the young

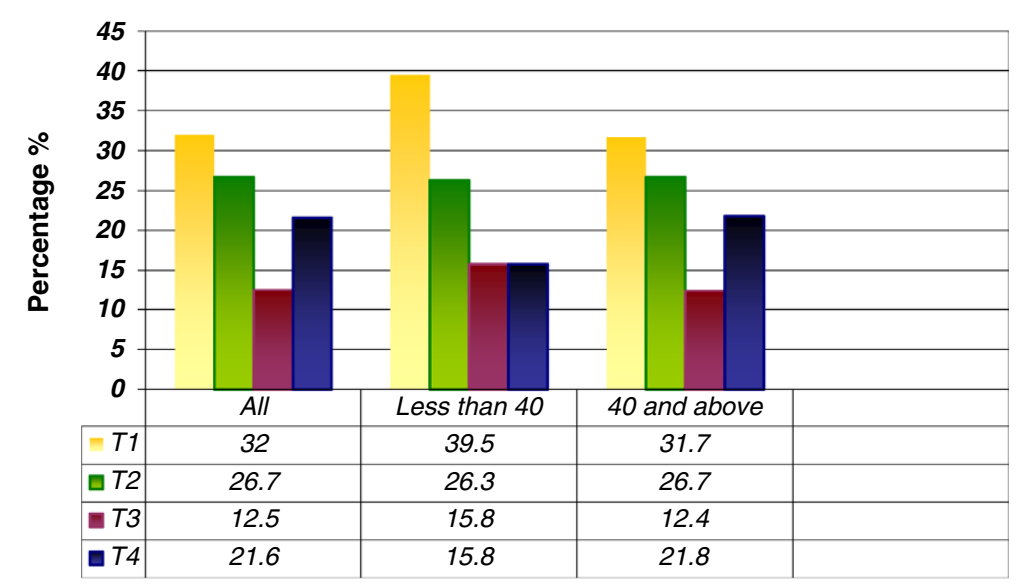

Figure 2 T-stages (based on T1-T4) by age groups of patients $(\mathbf{n}=\mathbf{9 7 7})$. A comparison of the patients less than 40 years with those older than 40 years shows no significant result using the log-rank test. 


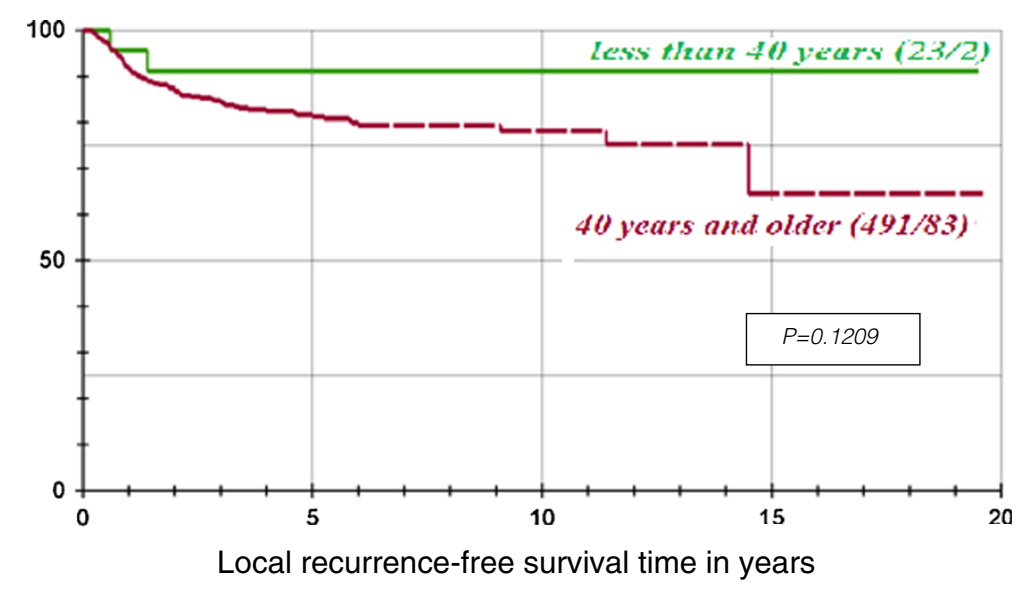

Figure 3 Graphical representation of the local recurrence-free survival time, of the 2 age groups, with the help of the product-limit method of Kaplan-Meier.

patients' population and this site also accounted only for $1.3 \%$ of the tumour location in the general study population.

Oral cavity and oropharyngeal SCC in the young patients has been linked with history of exposure to human papilloma virus (HPV), herpes simplex virus (HSV), human immunodeficiency virus (HIV), and some other viral infective diseases, although their causative role remains to be established $[6,19,20]$. The fact that even when these young patients indulge in known risk factors of alcohol and smoking, it is for considerably shorter periods compared to the adult counterparts as to induce oral carcinogenesis $[3,19]$ leaves room for further search as to other responsible aetiological factors. We cannot however draw any conclusions from our study as regards risk factor-tumour location association since our retrospective review did not include any of the viral risk factors.
As regards the tumour staging and grading, there was no significant difference between the groups of patients less than 40 years and those above 40 using the log-rank test (tables 2 and 3 , Figure 2). $\mathrm{T}_{1}$ and $\mathrm{T}_{2}$ tumours were the predominant stages for both groups and majority were moderately differentiated tumours. Mallet et al. [2] in a multi-centre analysis of head and neck SCC in young patients in France also reported that most of their patients presented with $T_{1}$ and $T_{2}$ tumours. But of significance in our report however is the result showing that males presented with larger tumours than females at diagnosis $(\mathrm{p}=0.005)$. This underscores the fact that women generally take better care of their bodies than men and visit the hospitals for check-ups more frequently than men do [21].

There is a general claim by some authors that patients in the younger age group have a more aggressive disease with a higher incidence of local recurrence or regional

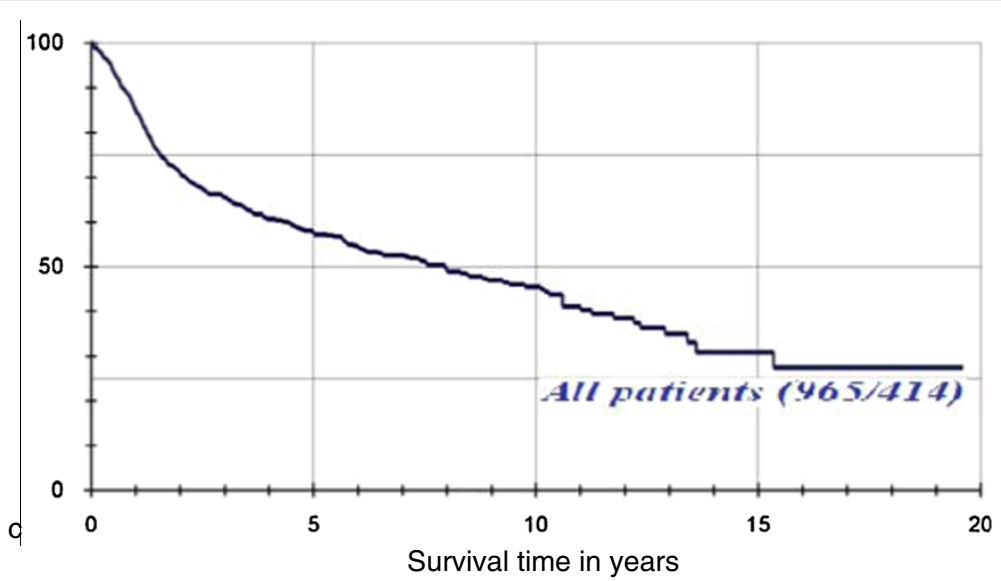

Figure 4 Graphical representation of the survival probability of the entire group, with the help the product-limit method of Kaplan-Meier. 


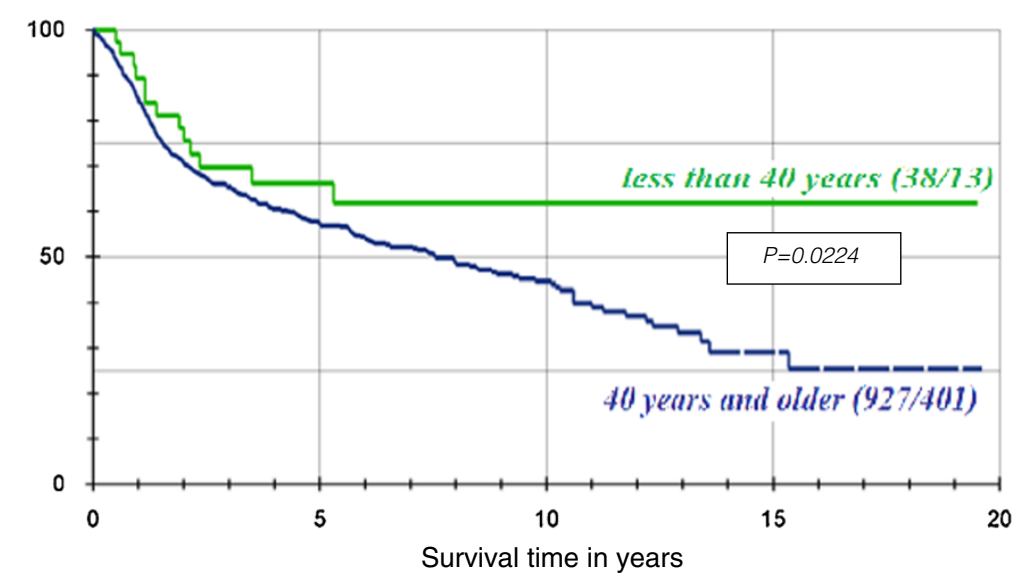

Figure 5 Graphical representation of the survival probability of the 2 age groups, with the help of the product-limit method of Kaplan-Meier.

lymph node involvement after treatment compared with older patients $[10,22]$. Our comparison of the local recurrence-free survival for the group less than 40 years and the group above 40 years using the log-rank test yielded no significant result $(\mathrm{p}=0.1209)$. The only observed discrepancy in this regard was that the young patients did not show sign of recurrences after 2 years whereas in the older patients, there were recurrences even after 10 years following treatment (Figure 3). This may be expected because drinking and smoking habits are more prevalent in the older age group and hence can result in a significantly increased risk of second and subsequent smoking-related cancers [23].

Our records show that at the end of the study period, 13 (34.2\%) out of the 38 patients in the young group had died of the tumour and 401 (42.7\%) out of 927 in older patients' group had also died from the tumour. The overall 5-year survival was found to be $66.2 \%$ and $57.2 \%$ in patients less than 40 years and those above 40 years respectively. This was found to be statistically significant when compared using the log-rank test $(\mathrm{p}=0.0224)$. Before we jump to the conclusion that younger patients have a better prognosis based on the above findings, we should remember the effect of comorbidities on head and neck cancer patients which affects the older patients more [24]. Patients with higher comorbid burden are likely to die earlier due to concurrent illness compared to those who are otherwise free of diseases apart from head and neck cancer [25]. This will therefore affect the overall survival of the patient [26].

\section{Conclusions}

Our review revealed that patients less than 40 years with SCC of OC and OP have a comparable histopathologic features and clinical course with those older than 40 years of age. Their local recurrence-free survival also shows no statistical significant difference, however, the 5-year overall survival is better in the young adult group than in the older patients' group. This goes to show that there may not be need for a more aggressive treatment for young patients with SCC of the OC and OP as is being advocated in some literature.

\section{Competing interests}

The authors declare that they have no competing interests.

\section{Acknowledgements}

The article processing charges are funded by the Deutsche Forschungsgemeinschaft (DFG), "Open Access Publizieren".

\section{Author details}

${ }^{1}$ Department of Oral and Maxillofacial Surgery, University of Port Harcourt Teaching Hospital, Port Harcourt, Nigeria. ${ }^{2}$ Department of Cranio-Maxillofacial Surgery, Hannover Medical School, Carl-Neuberg-Strasse 1, 30625, Hannover, Germany. ${ }^{3}$ Clinical Tumor Registry, Hannover Medical School, Hannover, Alemanya.

\section{Authors' contributions}

SEU, AME made substantial contributions to conception and design of the manuscript as well as data acquisition. MR has been involved in drafting the manuscript. WG was involved in data acquisition and statistical analysis. NCG was involved in revising the manuscript. All authors read and approved the final manuscript.

Received: 16 May 2012 Accepted: 30 May 2012

Published: 30 May 2012

\section{References}

1. Hart AE, Karakla DW, Pitman KT, Adams JF: Oral and oropharyngeal squamous cell carcinoma in young adults: a report on 13 cases and review of the literature. Otolaryngol Head Neck Surg 1999, 120:828-833.

2. Mallet $Y$, Avalos N, Le Ridant A, Gangloff $P$, Moriniere S, Rame J, et al: Head and Neck cancer in young people: a series of 52 SCCs of the oral tongue in patients aged 35 years or less. Acta Otolaryngol 2009, 129:1503-1508.

3. Oliver RJ, Dearing J, Hindle I: Oral cancer in young adults: report of three cases and review of the literature. BDJ 2000, 188:362-366.

4. Müller S, Pan Y, Li R, Chi AC: Changing trends in oral squamous cell carcinoma with particular reference to young patients: 1971-2006, The Emory University experience. Head Neck Pathol 2008, 2:60-66.

5. Hirota SK, Migliari DA, Sugaya NN: Oral squamous cell carcinoma in a young patient - case report and literature review. An Bras Dermatol 2006, 81:251-254. 
6. Salem A: Dismissing links between HPV and aggressive tongue cancer in young patients. Ann Oncol 2010, 21:13-17.

7. Patel SC, Carpenter WR, Tyree S, Couch ME, Weissler M, Hackman T, et al: Increasing incidence of oral tongue squamous cell carcinoma in young white women, age 18 to 44 years. J Clin Oncol 2011, doi:10.1200/ JCO.2010.31.7883.

8. Pytynia KB, Grant JR, Etzel CJ, Roberts D, Wei Q, Sturgis EM: Matched analysis of survival in patients with squamous cell carcinoma of the head and neck diagnosed before and after 40 years of age. Arch Otolaryngol Head Neck Surg 2004, 130:869-873.

9. Hyam DM, Conway RC, Sathiyaseelan Y, Gebski V, Morgan GJ, Walker DM, Veness MJ: Tongue cancer: do patients younger than 40 do worse? Aust Dent J 2003, 48:50-54.

10. Sarkaria JN, Harari PM: Oral tongue cancer in young adults less than 40 years of age: rationale for aggressive therapy. Head Neck 1994, 16:107-111.

11. Lacy PD, Piccirillo JF, Merritt MG, Zequeira MR: Head and neck squamous cell carcinoma: better to be young. Otolaryngol Head Neck Surg 2000, 122:253-258.

12. Jones AS, Beasley N, Houghton D, Husband DJ: The effects of age on survival and other parameters in squamous cell carcinoma of the oral cavity, pharynx and larynx. Clin Otolaryngol 1998, 23:51-56.

13. Llewellyn $C D$, Johnson NW, Warnakulasuriya KA: Risk factors for squamous cell carcinoma of the oral cavity in young people - a comprehensive literature review. Oral Oncol 2001, 37:401-418.

14. Toner M, O'Regan EM: Head and neck squamous cell carcinoma in the young: a spectrum or a distinct group? Part 1. Head Neck Pathol 2009, 3:246-248.

15. Martin-Granizo R, Rodriguez-Campo F, Gonzalez FJD: Squamous cell carcinoma of the oral cavity in patients younger than 40 years. Otolaryngol Head Neck Surg 1997, 117:268-275.

16. Mackenzie J, Ah-See K, Thakker N, Sloan P, Maran AG, Birch J, et al: Increasing incidence of oral cancer amongst young persons: what is the aetiology? Oral Oncol 2000, 36:387-389.

17. Iype EM, Pandey M, Matthew A, Thomas G, Sebastian P, Nair MK: Oral cancer among patients under the age of 35 years. J Postgrad Med 2001, 47:171-176.

18. Cusumano RJ, Persky MS: Squamous cell carcinoma of the oral cavity and oropharynx in young adults. Head Neck Surg 1988, 10:229-234.

19. Hirota SK, Braga FPF, Penha SS, Sugaya NN, Dante AM: Risk factors for oral squamous cell carcinoma in young and older Brazilian patients: a comparative analysis. Med Oral Patol Oral Cir Bucal 2008, 13:227-231.

20. Porter S, Waugh A: Comment on: oral cancer in young adults. BDJ 2000, 188:366.

21. Llewellyn CD, Linklater K, Bell J, Johnson NW, Warnakulasuriya KAAS: Squamous cell carcinoma of the oral cavity in patients aged 45 years and under: a descriptive analysis of 116 cases diagnosed in the South East of England from 1990-1997. Oral Oncol 2003, 39:106-114.

22. Garavello W, Spreafico R, Gaini RM: Oral tongue cancer in young patients: a matched analysis. Oral Oncol 2007, 43:894-897.

23. Siegelmann-Danieli N, Hanlon A, Ridge JA, Padmore R, Fein DA, Langer CJ: Oral tongue cancer in patients less than 45 years old: institutional experience and comparison with older patients. J Clin Oncol 1998, 16:745-753.

24. Sanabria A, Carvalho AL, Vartanian JG, Magrin J, Ikeda MK, Kowalski LP: Comorbidity is a prognostic factor in elderly patients with head and neck cancer. Ann Surg Oncol 2007, 14:1449-1457.

25. Paleri V, Wight RG, Silver CE, Haigentz M Jr, Takes RP, Bradley PJ, et al: Comorbidity in head and neck cancer: a critical appraisal and recommendations for practice. Oral Oncol 2010, 46:712-719.

26. Datema FR, Ferrier MB, van der Schroeff MP, Baatenburg de Jong RJ: Impact of comorbidity on short-term mortality and overall survival of head and neck cancer patients. Head Neck 2010, 32:728-736.

doi:10.1186/1758-3284-4-28

Cite this article as: Udeabor et al: Squamous cell carcinoma of the oral cavity and the oropharynx in patients less than 40 years of age: a 20-year analysis. Head \& Neck Oncology 2012 4:28.

\section{Submit your next manuscript to BioMed Central and take full advantage of:}

- Convenient online submission

- Thorough peer review

- No space constraints or color figure charges

- Immediate publication on acceptance

- Inclusion in PubMed, CAS, Scopus and Google Scholar

- Research which is freely available for redistribution 